DOI: $10.2478 / \mathrm{v} 10122-012-0012-2$

\title{
THE MIXING OF PASSIVE AND NON-PASSIVE RESULTATIVE ADJECTIVES IN POLISH ${ }^{1}$
}

\author{
BOŻENA CETNAROWSKA
}

\begin{abstract}
Bożena Cetnarowska. The Mixing of Passive and Non-Passive Resultative Adjectives in Polish. Lingua Posnaniensis, vol. LIV (2)/2012. The Poznań Society for the Advancement of the Arts and Sciences. PL ISSN 0079-4740, ISBN 978-83-7654-252-2, pp. 23-35.

The present paper aims to investigate the class of Polish resultative adjectives. Section 1 gives a brief overview of participial adjectives in Polish, referred to as "resultatives" in studies on Polish wordformation. Sections 2 and 3 examine the ambiguity between perfect and resultative interpretation of participial adjectives, as well as the distinction between subject-oriented and object-oriented adjectives. The discussion in sections 4-6 focuses on the rivalry between two adjectivizing suffixes in Polish: the suffix - $t$ - (which also appears in past tense forms) and the suffix $-n-/-t$ - (which functions as a passive marker). Special attention is paid to the occurrence of novel nonstandard S-oriented resultative adjectives terminating in -nięty, such as wyblaknięty (colloq.) 'faded'.
\end{abstract}

Bożena Cetnarowska, Institute of English, University of Silesia, Grota-Roweckiego 5, PL - 41-205 Sosnowiec, bozena.cetnarowska@us.edu.pl

\section{IDENTIFYING THE CLASS OF RESULTATIVE ADJECTIVES IN POLISH}

According to Nedjalkov (2001: 928) or Nedjalkov \& Jaxontov (1988: 6), resultatives are verb forms or deverbal derivatives denoting a state which implies some previous event (from which it has resulted).

Various accounts of Polish word-formation recognize resultatives as a subtype of deverbal adjectives. The formations given in (1) are treated as Polish resultative adjectives by GrZegorCZyKowa (1982: 64-66), who points out that they express qualities or state of an entity which result from a process denoted by the basic verb. She labels them "resultative action adjectives" (Pol. przymiotniki czynnościowe rezultatywne). ${ }^{2}$

1 This is a substantially revised version of the paper presented at the Poznań Linguistic Meeting 2011. I am grateful to the participants of the conference, the anonymous reviewer and the editors of the volume for their comments.

2 GrzegorczyKowa (1982: 65) also notices that deverbal adjectives terminating in -ny, such as najemny 'hired, that can be hired' (zotnierz najemny 'mercenary') and oprawny 'that has been bound' (oprawna ksiazka 'a book that has been bound'), can exhibit the resultative interpretation, in addition to the meaning of passive possibility ('such that can be V-ed'). 
(1a)

KaLlas (1984: 410), in turn, identifies a semantic class of deverbal adjectives called "stative adjectives" (Pol. przymiotniki stanowe) ${ }^{3}$ which express states (qualities) that come into being when a particular process takes place. ${ }^{4}$ She provides examples such as those in (2) below:

$$
\begin{aligned}
& \text { zbiegly jeniec 'escaped prisoner' (from zbiec (pf.) 'to escape') } \\
& \text { zgnite jabtko 'rotten apple' (from zgnić (pf.) 'to become rotten') } \\
& \text { zaginiony lad 'lost land' (from zaginać (pf.) 'to become lost') }
\end{aligned}
$$

The usage of the label "stative adjective" in KaLLAS (1984) differs slightly from the definition of the term provided in Nedjalkov (2001). He asserts that statives are deverbal or verbal forms which "express a state or an entity without implying a previous event" (NEDJALKOv 2001: 928), e.g. the adjective shut in the sentence When I came in at five, the door was shut (from NEDJALKOv 2001: 937). Adjectives such as zbiegly 'escaped' or zgnity 'rotten' in (2a-b) do seem to presuppose the occurrence of some event. NEDJALKOv (2001) points out, however, that it is not always easy to distinguish between the stative and resultative meanings, thus the term "resultative" can be used in the broad sense to include both statives and resultatives proper.

The formations terminating in -ty, such as oślepty 'blinded' in (1a) and zbiegly 'escaped' in (2a) are, from the diachronic point of view, adjectivized past participles (as noted in BARTNICKA 1970). Some scholars (e.g. ToKARSKi 2001; BaŃKo 2001; SALONI et al. 2007) continue treating attributive - $t y$ forms as adjectival past participles, though others do not regard them as (verbal) participles but as deverbal adjectives (GRZEGORCZYKOWA 1982; KALLAS 1984).

Let us consider, in turn, the -n-/-t- suffix$x^{5}$, visible in such forms as zaginiony 'lost' or uśmiechnięty 'smiling'. Its main function is to derive passive participles, which can follow the auxiliary verbs byc 'to be' or zostać 'to become'(in periphrastic passive forms) and which can appear as premodifiers of head nouns (as in 3e-f).

$$
\text { Dziadek pomalowat wszystkie ploty na zielono. }
$$

'The grandpa painted all the fences green.'

Wszystkie płoty zostaty pomalowane na zielono (przez dziadka).

'All the fences were painted green (by the grandpa).'

Wszystkie płoty sa pomalowane na zielono.

'All (the) fences are painted green.'

Plot jest właśnie malowany na zielono.

'The fence is being painted green just now.'

pomalowane na zielono ploty '(the) fences painted green'

malowany właśnie na zielono plot 'the fence which is being painted green just now'

3 The class of "resultative action adjectives" postulated in GRZEGORCZYKOWA (1982) roughly corresponds to "stative adjectives" in KaLlas 1984.

4 Additionally, Kallas (1984: 413) identifies a class of derived adjectives which denote the relationship between an event (i.e. action, process etc.) and its result, e.g. cięty 'cut' (cf. rana cięta 'incised wound'), wzruszony 'touched, moved' (cf. wzruszony glos 'voice showing emotions').

5 The distribution of $-n$ - and $-t$ - variants of the suffix is described in, among others, LASKOWSKI (1984) and TOKARSKI (2001). 
Sentence (3d) shows the occurrence of the auxiliary verb byc 'to be' with an eventive passive derived from an imperfective verb. The combination of a passive participle of a perfective verb (such as pomalować (pf.) 'to paint') with the verb zostać 'to become' (in $3 \mathrm{~b}$ ) expresses a dynamic (eventive) passive. The combination of the same (perfective) participle with the verb byc' 'to be' represents a stative passive (in 3c). BRAJERSKI (1972: 39) employs the term "stative-resultative" with respect to the function of passive forms exemplified in $(3 \mathrm{c})$.

The formations with the suffix -n-/-t- in (1c-d) and $(2 \mathrm{c})$ correspond to perfective intransitive verbs (usually accompanied by the reflexive clitic się), such as uśmiechnać się 'to smile', wyspać się 'to have a good sleep', zaginać 'to get lost'. Consequently, such -n-/-tparticipial adjectives are not passive participles proper and cannot occur in the periphrastic passive construction with the auxiliary verb zostać 'to become'. Nevertheless, SALONI et al. (2007) treat them as adjectival passive participles (due to the presence of the $-n-/-t$ - suffix), and keep them apart from adjectival past participles (terminating in -ty), such as zgnity 'rotten'.

There occur also - $n$-/-t- formations which are related formally to (transitive) imperfective verbs but denote a state presupposing the completion of some process (or action). For instance, the adjective malowany 'painted' is derived from the imperfective (unprefixed) verb malować (impf.) 'to paint'. When occurring in the phrase reccznie malowany jedwabny szal 'hand-painted silk scarf', it denotes a scarf which has been painted (rather than one which is in the process of being painted). For this reason, BAŃKO (2001: 254) includes the latter formation in the class of passive resultative participles. ${ }^{6}$

\section{RESULTATIVES VS. PERFECTS}

The category of resultatives is close to the category of perfects. NeDJALKov (2001: 930) defines the perfect as "a form that expresses an action (process or state) in the past which has continuous relevance for the present". Perfect forms differ from resultatives in the range of temporal adverbials with which they co-occur.

Resultatives freely combine with temporal phrases such as 'for x time' (e.g. od $d$ wóch $d n i$ 'for two days') denoting the duration of the state. If they are resultatives of temporary states, they can occur with the adverb nadal 'still' (which is not possible for resultatives denoting permament or irreversible states, such as zmarly 'dead'). This can be shown for -ny/-ty and -ty adjectives denoting states, especially expressing emotional states (e.g. zmartwiony 'worried', zdenerwowany 'irritated, annoyed', zmęczony 'tired', przygnębiony 'depressed').

$$
\begin{aligned}
& \text { Pawet jest od tygodnia zmartwiony i przygnębiony. } \\
& \text { 'Paweł has been worried and depressed for a week.' } \\
& \text { Maria jest nadal zdenerwowana, a jej maż jest nadal uśmiechnięty i zrelaksowany. } \\
& \text { 'Maria is still irritated and her husband is still smiling and relaxed.' } \\
& \text { zeschnięty od wczoraj chleb 'bread which has been dry since yesterday' } \\
& \text { zardzewiata od miesiaca brama 'a gate which has been rusty for a month' }
\end{aligned}
$$

6 BAŃKo (2001: 254) postulates two subtypes of resultative participles in Polish: active resultative participles, such as zeschnięty or zeschty 'dried, withered', and passive resultative participles (e.g. malowany 'painted'). 
Resultative adjectives, such as those in (4), can be contrasted with adjectives which exhibit perfect non-stative reading, such as those in (6-7) below. Perfect adjectives unlike resultatives, cannot occur with the adverb nadal 'still'. They can combine with temporal adverbials denoting the moment when a given event takes place, e.g. $d w a$ dni temu 'two days ago' or przed rokiem '(lit. before a year) a year ago'.

Some participial adjectives (containing either the suffix $-n-/-t-$ or $-t-$ ) are ambiguous between perfect and resultative interpretation. For instance, the adjectives owdowiaty 'widowed', rozwiedziony 'divorced' and internowany 'interned', can follow the adverb nadal 'still' and are compatible both with the temporal phrases od roku 'for a year' and rok temu 'a year ago'.

owdowiaty od roku mężczyzna 'a man who has been widowed for a year' owdowiaty przed rokiem mężczyzna 'a man who was widowed last year' mój rozwiedziony od miesiąca kuzyn 'my cousin who has been divorced for a month' mój rozwiedziony przed miesiącem kuzyn 'my cousin who got divorced last month' internowani od roku działacze Solidarności 'Solidarity activists who have/had been interned for a year'

internowani przed rokiem działacze Solidarności 'Solidarity activists who were interned a year ago'

Selected participial adjectives terminating in - ty are not resultatives proper but perfects, as is shown in (6-7) below for przybyty 'arrived' and zbiegly 'escaped'.

(6a) przybyly przed godzina postaniec 'a messenger that arrived an hour ago'

(6b) *przybyty od godziny postaniec '?a messenger that has been arrived for an hour'

(6c) przybyty niedawno postaniec 'a messenger that arrived recently'

(6d) *nadal przybyly postaniec '?a still arrived messenger'

(7a) zbiegly przed tygodniem więzien' 'a prisoner that escaped a week ago'

(7b) ?*zbiegly od tygodnia więzien' '?a prisoner that has been escaped for a week'

(7c) ?*nadal zbiegly więzien' '?a still escaped prisoner'

Perfects such as przybyty 'arrived' will be included here in the broad class of resultative and resultative-like adjectives derived by means of the suffix $-n-/-t$ - or the suffix $-t$ -

\section{THE NOTION OF ORIENTATION}

There are several ways of dividing resultatives into subtypes (see NEDJALKOV 2001 for a useful survey). One of the crucial classifications is syntactically based, distinguishing between subject-oriented and object-oriented resultatives. Object-oriented deverbal adjectives in Polish, such as those in (8a), modify the head noun which corresponds to the object of the base verb.

pomalowany ptot 'painted fence'

Dziadek pomalowat ptot na zielono.

'The grandpa painted the fence green.'

zgaszone światto 'switched off light' 
Mama zgasita światto w pokoju.

'Mum switched off the light in the room.'

Cross-linguistically, subject-oriented deverbal adjectives can be of two types: they can either retain (i.e. be oriented towards) the subject of the intransitive base verbs, or the transitive base verb. Subject-oriented resultatives of the former type in Polish (i.e. oriented towards the subjects of intransitive verbs) are exemplified in (9):

$$
\text { zgnite ziemniaki 'rotten potatoes' }
$$

Ziemniaki (S) zgnity w piwnicy.

'(The) potatoes went rotten in the cellar.'

zaschnięty tusz do rzęs 'dried mascara'

Mój tusz do rzęs (S) zasecht po dwóch tygodniach.

'My mascara dried after two weeks.'

In the terminology employed in COMRIE (1981), adjectives such as those in (9a) and (9c) are referred to as S-oriented (i.e. oriented toward the subject of an intransitive verb), while the adjective in (8a) is P-oriented (i.e. modifying the object of the transitive verb).

The term A-orientation (in COMRIE 1981) denotes orientation toward the subject of a transitive verb. According to Nedjalkov \& Jaxontov (1988) and Nedjalkov (2001), A-resultatives are not very frequent cross-linguistically. They may be derived, for instance, from transitive verbs involving affected agents, i.e. "from transitives which describe situations changing (mostly or exclusively) the state of the agent rather than that of the patient" (Nedjalkov 2001: 932). In the case of Polish, the group of such A-oriented resultatives is represented by the adjectives najedzony 'fed, such that has taken enough food' or opity 'drunk'. There are also secondary A-oriented resultatives in Polish which occur in the construction with the auxiliary verb mieć 'to have', as in (10). ${ }^{7}$

$$
\begin{aligned}
& \text { Mamusia miała ubrany dtugi płaszcz. } \\
& \text { 'Mum was wearing a long coat.' } \\
& \text { Mam już wszystkie naczynia pomyte. } \\
& \text { 'I have all the dishes washed already.' }
\end{aligned}
$$

Instead of referring to syntactic notions, such as subject and object, one can specify the orientation of deverbal adjectives towards a particular semantic participant in the event denoted by the base verb (as in HASPELMATH 1994 and KiBORT 2005). Consequently, the passive participle pobity 'beaten up' will be described as oriented towards the Patient participant while the resultative adjective najedzony 'that has taken enough food' - as oriented towards the (affected) Agent. The adjectives zgnity 'rotten' and zaschnięty 'dried' in (9), in spite of being classified above as subjective resultatives, are oriented towards the Patient, i.e. a non-volitional participant which undergoes a change in the course of the situation. While BaŃKо (2001: 254) uses the term "active resultative participles" (Pol. imiestowy rezultatywne czynne) to denote $-n y /-t y$ and -ty participles which are oriented towards the single participant of the event (such as zeschly and zeschnięty 'withered'), I will employ here the term "non-passive resultative adjectives", to avoid the implication of the participles being oriented towards Agents.

7 This construction is discussed at length in ŁazińsKi (2001) and Kibort (2011). Nedjalkov (2001: 933) gives examples of secondary A-resultatives from Slovak. 


\section{MORPHOLOGICAL MARKING OF RESULTATIVE ADJECTIVES IN POLISH}

Nedjalkov \& Jaxontov (1988) show that languages vary in how they mark various types of resultatives. For instance, some languages (such as Chinese and Archi) have the subject-oriented and object-oriented resultatives marked in the same way while in other languages (e.g. in Lithuanian) each type of resultatives shows distinct morphological marking. ${ }^{8}$ Polish seems to belong to the latter group of languages, since it employs two distinct suffixes to form resultative adjectives: $-n-/-t$ - suffix (i.e. the passive suffix) or $-t$ - suffix (i.e. the past tense suffix). However, the "division of labour" between the two suffixes is far from being neat. The suffix - $t$ - is restricted to subject-oriented adjectives, e.g. zeschty 'dried', zgniły 'rotten', spleśniały 'mildewed'. One would expect the suffix - $n-/-t$ - to be similarly specialized, since it often functions as a marker of object-oriented resultatives, as in pomalowany 'painted' or pobity 'beaten up'. However, adjectives such as wyspany 'that has had enough sleep' or spierzchnięty '(of skin) chapped' are clearly S-oriented as they are derived from intransitive verbs, namely from wyspać się 'to get enough sleep' and spierzchnać 'to become chapped'.

It is interesting to observe that historically neither the suffix $-t$ - nor the suffix $-n-/-t$ functioned as unambiguous markers of subject-orientation or object-orientation of participial adjectives. OesterReICHER (1926) asserts that speakers of Polish were often uncertain as to the intended active, passive or reflexive interpretation of adjectival past (i.e -ty) participles. Polish passive (i.e. -ny/-ty) participles showed a similar instability in their diachronic development. As observed in Kleszczowa (2003), in the Old Polish period certain passive participles showed the meaning similar to present participles (terminating in -acy), as shown below.

$$
\text { zatruty (current meaning 'poisoned') - used in Old Polish in the sense 'such that can poison' }
$$
(cf. the present-day form trujacy 'poisonous')

zbawiony (current meaning 'that has been saved') - used in Old Polish in the sense of the current present participle zbawiajacy 'that brings salvation'

odstawiony (current passive meaning 'that has been put aside') - used in Old Polish in the sense of odstajacy 'sticking, protruding'.

One of the factors responsible for the frequent occurrence (in present-day Polish) of "non-passive" adjectives containing the passive marker (i.e. the -n-/-t- suffix), such as zaschnięty 'dried' in (9c), is the ambiguity of resultative adjectives derived from so-called alternating verbs (cf. LEVIN \& RAPPAPORT HOVAV 1995), i.e. verbs which occur either in transitive or intransitive (non-causative) usage.

\section{Ten kierowca złamat prawo.}

'This driver broke the law.'

$$
\text { złamane prawo 'broken law' (passive reading, object-oriented adjective) }
$$

Gałęzie drzewa złamaly się na wietrze.

'The branches of the tree broke in the wind'.

złamane na wietrze gatęzie 'broken branches, i.e. ones that broke by themselves, in the wind' (non-passive reading, subject-oriented adjective).

8 In Lithuanian object-oriented resultatives are marked with the passive suffix while S-resultatives and A-resultatives are rendered by the perfect active form (NeDJALKov 2001: 932). 
Although the participial adjective złamany 'broken' in (12b) is object-oriented while in (12d) it is subject-oriented, in both cases the adjective describes the semantic participant with the role of the Patient.

The occurrence of both passive and non-passive readings of -ny/-ty adjectival participles derived from alternating verbs (e.g. złamać (sie) 'to break) must have paved the way for the formation of such adjectives from verbs which allow only intransitive reflexive usage (as in 13 ), or only intransitive non-reflexive one (in 14):

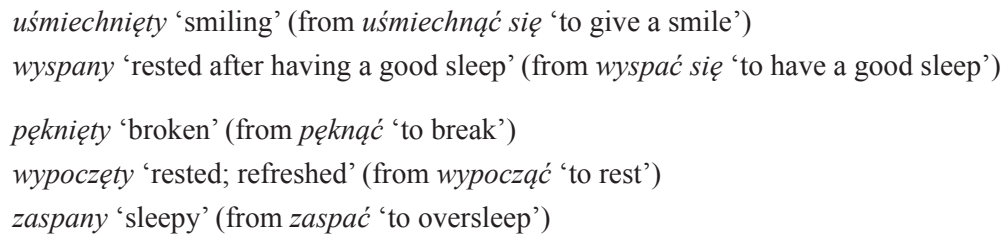

The next section will exemplify the occurrence of adjectival doublets of subject-oriented adjectives, derived from the same verbal base but containing either the $-n-/-t$ - suffix or the $-t$ - suffix.

\section{COMPETITION BETWEEN - $n-/-t$ - AND - $t$ - ADJECTIVES: ADJECTIVAL DOUBLETS}

The competing resultative adjectives containing the suffix $-t$ - or the suffix $-n-/-t$ - occasionally differ both in register and in meaning:

$$
\begin{aligned}
& \text { padty '(esp. of animals) dead'vs. padnięty (colloq.) '(of people) dead tired; (of objects) broken' } \\
& \text { (from paść 'to fall; to die; to break down') } \\
& \text { wyrosty 'that has grown or developed from sth' vs. wyrośnięty (colloq.) 'that has grown (too } \\
& \text { quickly)' (from wyrosnać 'to grow') }
\end{aligned}
$$

However, the resultative adjectives in (16) below are synonymous (within each pair) and they differ mainly in their frequency of occurrence and in stylistic marking. ${ }^{9}$ The forms with the suffix - $n-/-t$ - given in (16) can occur either in more formal or less formal registers of Polish. The adjectives in (16) terminating in -ty are characteristic of literary Polish, thus they are less common than their -ny/-ty equivalents. ${ }^{10}$

$$
\begin{aligned}
& \text { zmoknięty or zmokly (rare) 'soaking wet' (from zmoknać 'to get wet') } \\
& \text { nasiąnięty or nasiakkly (rare) 'that has absorbed (water)' (from nasiaknać 'to absorb') } \\
& \text { namoknięty or namokly (rare) 'saturated (with water)' (from namoknać 'to become wet') } \\
& \text { spierzchnięty or spierzchty (rare) 'chapped (of skin)' (from spierzchnaćc 'to become chapped') }
\end{aligned}
$$

The tendency to form subject-oriented resultatives with the passive suffix $-n-/-t$ - (especially adjectives terminating in the sequence -nięty) has been on the increase in the past years. A quick search of Internet sources (such as blogs or Internet fora) testifies to the oc-

9 JABŁOŃSKA (2007: 273-275) adopts a different position and does not treat adjectival doublets, such as those in (16), as synonyms. She argues that $-n-/-t$ - participial adjectives show the stative reading but lack the eventive reading, while $-t$ - participles exhibit both readings.

${ }_{10}$ More examples of such adjectival pairs are given in CETNAROwSKa 2000 and 2012. In marking one of the competing forms as rare (or less common) in (16), I follow the judgments given in BAŃKo (2000, 2001), as well as my own judgments. 
currence of -ty adjectives which are not included in (conservative) normative dictionaries of Polish (such as DoroszewsKi 1993), e.g. rozkwitnięty 'blooming'.

rozkwitty or rozkwitnięty (colloq.) 'blooming' (cf. rozkwitnać 'to start blooming, to open') ostygly or ostygnięty (colloq.) 'that has cooled down' (cf. ostygnąc 'to cool down') urosty or urośnięty (colloq.) 'that has grown' (from urosnać 'to grow') wklęsty or wklęśnięty (colloq.) 'concave' (from wklęsnąc 'to subside') wyblakty or wyblaknięty (colloq.) 'faded' (from wyblaknąc 'to fade')

Makijaż albo udziwniony, przesadzony, zbyt mocny, albo wyblakniety i nijaki. ... (uroda.onet.pl) 'The make-up, either strange or exaggerated, too strong or faded and bland...' mieć wkleśniẹty brzuch $i$ wystające kości (perfect-weight.bloog.pl) 'to have concave stomach and protruding bones' po upieczeniu pieknie urośnięty sernik OKLAPŁ? (f.kuchnia.o2.pl) 'after baking, the beautifully grown (i.e. risen) cheesecake collapsed'

Such -nięty adjectives are not labelled here as incorrect forms, but are treated as innovative colloquial formations. They are recognized as well-formed in the recently published grammatical dictionary of Polish (i.e. SALONI et al. 2007). Moreover, most of them can be attested in the National Corpus of Polish, as shown by the examples given in (19) below. ${ }^{11}$

Kiedy kwiat będzie wystarczająco rozkwitnięty przesadze go do ogrodu. (text type: Internet, interactive texts, source: Usenet - pl.sci.psychologia)

[When the flower has bloomed sufficiently, I will transplant it into the garden.]

[...] jeżeli włosy na chorym miejscu stały się biate i jeżeli znak zdaje się być wklęśnięty w stosunku do skóry ciata, jest to plaga trąu. (text type: literature, non-fiction, source: Biblia Tysiąclecia)

[If the hair on the affected area has become white and the spot seems to be concave, in comparison to the body skin, this is the plague of leprosy.]

Various Internet texts include examples of further innovative S-oriented -nięty resultatives which are included neither in Doroszewski (1993) nor in SALONI et al. (2007). Such formations may be marked as ill-formed in dictionaries of correct Polish usage. One can consult, for instance, MARKowski (2004), LiCA (2001), Drabik \& Sobol (2006), who explicitly condemn the formations wychudnięty 'thinned'; osłabnięty 'that has grown weak' and oślepnięty 'that has gone blind'. The novel (or non-established) status of -nięty derivatives is often emphasized by the speakers themselves, since they use quotation marks (in writing) to introduce such items (as in 20c-d):

(20a) Ciagle się coś zmienia, więc czekając na zmiany jestem oślepnięty jakiśs. (www.przebudzenie.pl) [There are changes all the time so I'm sort of blinded waiting for them.]

(20b) Wygląda całkiem normalnie, nie jest $w$ żaden sposób wychudnięty. (www.sfd.pl/Wstręt_do_ jedzenia-t286962.html)

[He looks quite normal, and is not gaunt in any way.]

(20c) Wróciliśmy po 2, mężul coś taki „oslabnięty”, spat dziś do 10. (www.babyboom.p1/forum/dzieciurodzone-w-marcu-2008-f171)

[We came back after two (a.m.). my hubby [was] rather "weakened" and slept until ten (a.m.) today.]

${ }^{11}$ While collecting examples for the present paper, I used the demo version of the corpus (version 4, based on $1450 \mathrm{mln}$ segments), which is available online at http://nkjp.pl/poliqarp/nkjp-demo-4. The searches were carried out on 28 April 2011, and between 11 July and 1 August 2011. 
Usterka to ,wybuchnięty” kondensator w okolicach bloku zasilacza. (xarchiwum.p1/1/tunerunitra-t9015)

[The fault is the "exploded" capacitor in the area of the power supply unit.]

\section{THE IMPORTANCE OF ANALOGICAL LEVELLING}

It is crucial to notice that the novel subject-oriented resultatives containing the passive $-n-/-t-$ morpheme are derived from verbs containing the thematic suffix -na-.

In the inflectional typology presented in TOKARSKI (2001), Polish verbs are divided into eleven conjugation classes, depending on the type of the thematic suffix which is added to the verb root and surfaces in front of the past tense suffix, e.g. $-i$ - in palit 'smoke.PAST.3SG. MASC', $-a(j)$ - in czytat 'read.PAST.3SG.MASC', -nq- in krzyknat 'shout.PAST.3sG.MASC'. The thematic suffix determines the choice of the person-number-gender markers in finite verb forms, for instance the selection of $-m$ or $-e$ as the marker of the first person singular in non-past tense forms, cf. czytam 'read.PREs.1sG.', pale 'smoke.PREs.1SG', krzykne 'shout. FUT.1SG'.

In Tokarski's typology, verbs with the suffix -na- belong to Class V, which is further subdivided into three subgroups, listed below.

$$
\begin{aligned}
& \text { Group Va: szarpnać 'to pull with a quick movement; yank', kopnać 'to kick' } \\
& \text { Group Vb: plynać 'to swim', sunaćc 'to glide, to push' } \\
& \text { Group Vc: chudnać 'to thin', schudnać 'to lose weight, to slim down', ślepnać 'to go blind', } \\
& \text { oślepnać 'to become blind', kraść 'to steal', biec 'to run' }
\end{aligned}
$$

The suffix -nq- exhibits various semantic functions. In verbs belonging to Group Va it exhibits the semelfactive reading, i.e. it denotes a single occurrence of a state of affairs with short duration. The related imperfective verbs show iterative or habitual reading (see $22 \mathrm{a}-\mathrm{b})$. In the case of the verbs from Group $\mathrm{Vb}$, the imperfective verbs describe non-directed and aimless movement, in contrast to the directed aim-oriented movement denoted by the perfective -nq-verbs (as shown in 23). In verbs from Group Vc the suffix -nq- has the verbalizing and inchoative function. ${ }^{12}$ It occurs in deadjectival verbs denoting change of state (as in 24), which in turn can give rise to S-oriented resultative adjectives, such as those mentioned in the previous section of this paper.

$$
\begin{aligned}
& \text { szarpać (impf.) 'to pull, to give several pulls'- szarpnać (pf.) 'to give a quick pull' } \\
& \text { krzyczeć (impf.) 'to shout' - krzyknać (pf) 'to give a shout, to shout once' } \\
& \text { plynać (impf.) 'to swim'- plywać (impf.) 'to swim (habitually or in various directions), to swim } \\
& \text { around' } \\
& \text { przeptyną́ (pf.) 'to swim (across sth) - przeptywać (impf.) 'to swim (across sth)' } \\
& \text { chudnać (impf.) 'to be slimming down' - schudnać (pf.) 'to slim down, to lose weight' } \\
& \text { ślepnać (impf.) 'to go blind'- oślepnać (pf.) 'to become blind' }
\end{aligned}
$$

${ }^{12}$ For instance, the suffix -nq- has a verbalizing function in the lexeme ślepnać 'to become blind' as it marks a change in the syntactic category of its derivational base ślepy 'blind' (from an adjective to a verb). Additionally, the suffix -nq- exhibits here an inchoative function since the verb in which it occurs denotes a non-causative change of state. 
The basic difference between subgroups of Class V verbs for ToKARSKI (2001) lies not in the semantics of the -na- suffix but in the verbs' conjugation patterns. ${ }^{13}$ Verbs in groups Va and Vc contain the sequence -nij- in the stem of the imperative forms whereas verbs in groups $\mathrm{Vb}$ contain the formative - $n$ - (cf. szarpnij 'yank.IMPER.2sG', kradnij 'steal. IMPER.2sG', ptyń 'swim.IMPER.2sG', suń 'glide.IMPER.2sG'). Some of the verbs in group Vc lack the suffix -nq- in the infinitive (e.g. kraść 'to steal'). Verbs in group Va exhibit the presence of the suffix -na- in the past tense forms while verbs in group Vc lack the suffix in those forms.

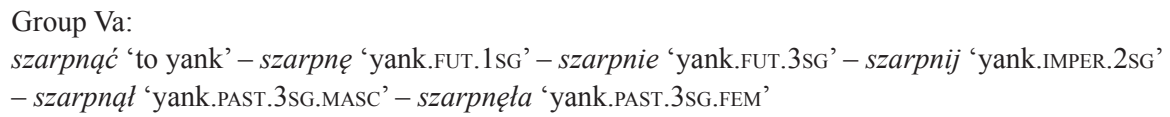

Group Vb:

plynać 'to swim' - plynę 'swim.PRES.1SG' - plynie 'swim.PRES.3SG' - plyn' 'swim.IMPER.2SG' plynąt 'swim.PAST.3sG.MASC' - plynęta 'swim.PAST.3SG.FEM'

\section{Group Vc:}

chudnać 'to thin' - chudnę 'thin.PRES.1SG' - chudnie 'thin.PRES.3SG' - chudnij 'thin.IMPER.2SG' chudt (or chudnat) 'thin.PAST.3SG.MASC' - chudla 'thin.PAST.3SG.FEM'

Speakers of Polish tend to confuse verbs from group Va (which contain the suffix -nain past tense forms) with verbs from group Vc (where the suffix -nq-is absent in finite past tense forms), producing forms such as those in (28): kopnać 'to give a kick’ (Va), kopnęła (not *kopła) 'kick.PAST.3SG.FEM’ (TOKARSKi 2001: 216) rosnać 'to grow' (Vc), róst (not * rosnąt) 'grow.PASt.3sG.MASC', rosta (not * rosnęta) 'grow. PAST.3SG.FEM' (JADACKA 2006: 95) paść 'to fall down' (Vc), padtem (not *padnątem or *padnętem) 'fall-down.PASt.1sG.MASC' (LicA 2001)

Moreover, not all past tense forms of a given verb may show the same shape of the stem, i.e. the extended stem with the suffix $-n a$ - or the shortened stem without the $-n a$ - suffix. ${ }^{14}$

Dictionaries of correct Polish or dictionaries of the Polish language contain judgments on which past tense forms of a particular verb can retain the suffix -na- and which cannot exhibit the suffix. Authors of such dictionaries frequently give conflicting advice (which may be due to the difference in their date of publication).

$$
\begin{aligned}
& \text { wychudnać 'to thin', wychudlem (not: *wychudnatem) 'thin.PAST.1SG.MASC', wychudt or } \\
& \text { wychudnat 'thin.PAST.3SG.MASC', wychudta (not *wychudnęta) 'thin.PAST.3SG.FEM', wychudliśmy } \\
& \text { (not *wychudnęliśmy) 'thin.PAST.1 PL.MASC' (MARKOwSKI 2004). (NB: DoROSZEWSKI 1993: } \\
& \text { wychudt, not *wychudnat 'thin.PAST.3SG.MASC') }
\end{aligned}
$$

${ }^{13}$ In the semantic classification of verbs proposed in LASKOWSKI (1998), -na- verbs from group Va can be identified as denoting acts (i.e. momentary and controlled events), e.g. szarpnąc 'to pull', or happenings (i.e. momentary and uncontrolled events), e.g. kichnać 'to sneeze'. Verbs in group $\mathrm{Vb}$ can denote activities (i.e. atelic durative and controlled situations), e.g. plynać (impf.) 'to swim', or actions (i.e. telic durative and controlled situations), such as przeptynać (pf.) 'to swim (across sth)'. The majority of items in group Vc are processual verbs, such as spierzchnać 'to become chapped', denoting durative telic situations which are not controlled by the main participant.

${ }^{14}$ This is discussed in LasKowsKI (1998: 244-245). 
ostabnać 'to weaken', ostabtem or ostabnatem 'weaken.PAST.1SG.MASC', ostabt or ostabnat 'weaken.PAST.3SG.MASC', osłabła (not *ostabnęta) 'weaken.PAST.3sG.FEM', ostabliśmy or osłabnęliśmy 'weaken.PAST.1PL.MASC' (MARKOWSKi 2004) (NB: DorosZEWSKI 1993: osłabt 'weaken.PAST.3sG.MASC', not *ostabnat; osłabliśmy 'weaken.PAST.1PL.MASC', no mention of ostabnęliśmy).

The formation of novel past tense forms with the suffix -nq-, such as wychudnat 'thin. PAST.3SG.MASC' and ostabnęliśmy 'weaken.PAST.1PL.MASC', leads to the elimination of allomorphy, since the extended stem with the suffix - nq- occurs in other verb forms, e.g. present/ future tense forms and infinitive forms.

The pressure towards the preservation of -nq- suffix in resultative adjectives may be interpreted as pressure towards the consistency of the stem form within an extended conjugational paradigm. ${ }^{15}$ Notice that resultative adjectives in - $t y$ do not contain the -nq- suffix, even if corresponding past tense forms optionally do. In contrast, the passive or non-passive adjectives in -t- retain the -nq- suffix: the morphemes -nq-and -t(y) form the sequence -nięty, as in zmoknięty 'wet'. They resemble verbal (i.e. gerundive) -nie/-cie nouns in this respect. ${ }^{16}$

zmokly ptak 'wet bird' (not *zmoknęly ptak) (see zmókł or zmoknąt 'wet.PAST.3sG.MASC') vs. zmoknięty ptak 'wet bird', cf. zmoknąc (pf.) 'to become wet', zmoknięcie 'becoming wet'

oklapte ucho 'droopy ear' (not *oklapnęte ucho) (see oklapt or oklapnąt 'droop.PAST.3sG.MASC') vs. oklapnięte ucho 'droopy ear', cf. oklapnać (pf.) 'to droop, to collapse', oklapnięcie 'the act of drooping, the state of being droopy or showing lack of any enthusiasm'

Analogical levelling is the elimination (i.e. levelling) of a morphonological alternation in the stem (cf. Joseph 1998). In the case of analogical levelling speakers select the stem allomorph which is more frequent (e.g. which occurs in frequently used forms) and extend it in the paradigm. Thus, the phenomenon of analogical levelling is (partly) responsible for the occurrence of non-passive (i.e. S-oriented) resultatives with the passive morphology.

\section{CONCLUSIONS}

Resultative adjectives in Polish are deverbal (participial) adjectives which contain either the suffix $-n-l-t$ - (which functions as a passive marker) or the suffix - $t$ - (which occurs in finite past tense forms). It was shown above that selected adjectives terminating in -ny/-ty or -ty sequences allow both resultative and perfect meaning (e.g. rozwiedziony 'divorced'), while some -ty adjectives should be regarded as unambiguous perfect forms (e.g. przybyty 'that has arrived'). Adjectives terminating in $-t y$, such as spleśniaty 'mildewed', are all subject-oriented (which comes as no surprise, given that they are historically adjectival past participles). Adjectives terminating in -ny/-ty sequences are mainly object-oriented and show the passive meaning, e.g. zatruty 'poisoned' and zbudowany 'built'. However, there is a marked tendency in present-day Polish for intransitive (sometimes reflexive) verbs to derive subject-oriented resultatives with the suffix $-n-/-t$ - This phenomenon is particularly noticeable in the case of resultatives derived from verbs containing the thematic suffix -na-.

\footnotetext{
${ }^{15}$ Oesterreicher (1926: 22) noticed that several adjectives in $-t y$ became obsolete when they lacked the suffix $-n q$ - which occurs in the infinitive and in various finite forms, e.g. uklękly (obs.) 'that has knelt down'.

${ }^{16}$ In CETNAROWSKA 2012 I discuss (at greater length) the influence of verbal nouns on the formation of innovative subject-oriented resultative adjectives terminating in -nięty.
} 
A crucial factor identified above as responsible for the current expansion of S-oriented resultative formations terminating in -nięty is the pressure towards the preservation of the -na- suffix in finite verb forms, in verbal nouns and in participial adjectives. This results in the mixing of passive and non-passive resultative adjectives containing the same marker, i.e. the suffix $-n-/-t$.

\section{REFERENCES}

Bańko Mirosław (ed.). 2000. Inny słownik języka polskiego [A Different Dictionary of Polish]. Warszawa: Wydawnictwo Naukowe PWN.

BAŃKo Mirosław. 2001. Z pogranicza leksykografii i językoznawstwa [From the Crossroads of Lexicology and Linguistics]. Warszawa: Wydawnictwo Polonistyki Uniwersytetu Warszawskiego.

BARTNICKA Barbara. 1970. Adiektywizacja imiestowów w języku polskim [Adjectivization of Participles in Polish]. Warszawa: PWN.

Brajerski Tadeusz. 1972. "O polskiej stronie biernej” [On the Polish Passive Voice]. In: Zaleski 1972: 31-39.

ButT Miriam, KING Tracy Holloway (eds.). 2005. Proceedings of the LFG05 Conference, University of Bergen. Stanford, CA: CSLI Publications. Available online at: http://epubs.surrey.ac.uk/1071/1/fulltext.pdf.

CetnarowsKa Bożena. 2000. "Resultative Adjectives in Polish." Acta Linguistica Hungarica 47, 47-79.

Cetnarowska Bożena. 2012 "On the Expansion of Polish Resultative Adjectives Terminating in -nięty." In: Cyran et al. 2012: 71-105.

ComRIE Bernard. 1981. "Aspect and Voice: Some Reflexions on Perfect and Passive." In: Tedeschi \& Zaenen 1981: 65-78.

Cyran Eugeniusz, Kardela Henryk, Szymanek Bogdan (eds.). 2012. Sound Structure and Sense. Studies in Memory of Edmund Gussmann. Lublin: KUL University Press.

DoroszewsKi Witold (ed.). 1958-1969. Stownik języka polskiego [A Dictionary of the Polish Language], vol. 1-11. Warszawa: PWN (CD version. Warszawa: WN PWN, 2005).

Doroszewski Witold (ed.). 1993. Stownik poprawnej polszczyzny [A Dictionary of Correct Polish]. 17th edition. Warszawa: PWN (CD-ROM version 1997).

DrabiK Lidia, SoBol Elżbieta. 2006. Stownik poprawnej polszczyzny PWN [The PWN Dictionary of Correct Polish]. Warszawa: PWN.

Fox Barbara, Hopper Paul (eds.). 1994. Voice: Form and Function. Amsterdam: Benjamin.

GrZEGorczyKowa Renata. 1982. Zarys stowotwórstwa polskiego. Stowotwórstwo opisowe [A Sketch of Polish Word-formation. Descriptive Word-formation]. Warszawa: PWN.

GrzegorczyKowa Renata, LasKowski Roman, Wróbel Henryk (eds.). 1984. Gramatyka wspótczesnego języka polskiego. Morfologia [A Grammar of Present-day Polish. Morphology]. Warszawa: PWN.

GrZeGorczyKowa Renata, LASKOwSKI Roman, WróBel Henryk (eds.). 1998. Gramatyka wspótczesnego języka polskiego. Morfologia [A Grammar of Present-day Polish. Morphology]. 2nd edition revised. Warszawa: PWN.

Haspelmath Martin. 1994. “Passive Participles Across Languages.” In: Fox \& Hopper 1994: 151-177.

Haspelmath Martin, KöNig Ekkehard, Oesterreicher Wulf, Raible Wolfgang (eds.). 2001. Language Typology and Language Universals: An International Handbook, vol. 2: Syntactic Typology. Berlin: de Gruyter.

JABŁoŃSKA Patrycja. 2007. "Radical Decomposition and Argument Structure." (Unpublished PhD dissertation, University of Tromsǿ. Available online at http://www.ub.uit.no/munin/bitstream/handle/10037/991/thesis. pdf? sequence $=1$ ).

JADACKA Hanna. 2006. Kultura języka polskiego. Fleksja, słowotwórstwo, składnia [The Culture of the Polish Language. Inflection, Word-formation, Syntax]. Warszawa: Wydawnictwo Naukowe PWN.

Joseph Brian D. 1998. "Diachronic Morphology.” In: SPENCER \& ZWICKY 1998: 351-373.

Kallas Krystyna. 1984. "Słowotwórstwo przymiotników" [Adjectival Word-formation]. In: GrzegorczyKowa et. al. 1984: 408-455.

Kibort Anna. 2005. "The Ins and Outs of the Participle-adjective Conversion Rule.” In: ButT \& KING 2005: $205-225$. 
Kibort Anna. 2011. "The Elephant in the Room. The Impersonal -ne/-te Construction in Polish.” In: MALCHUKOV \& SiEWIERSKA 2011: 357-393.

Kleszczowa Krystyna. 2003. Staropolskie derywaty przymiotnikowe i ich perspektywiczna ewolucja [Derived Adjectives in Old Polish and Their Evolution]. Katowice: Wydawnictwo Uniwersytetu Śląskiego.

LASKOWSKi Roman. 1984. "Paradygmatyka" [Inflection]. In: GrZEGORCZYKOWA et al. 1984: 171-303.

LASKOWSKI Roman. 1998. "Paradygmatyka" [Inflection]. In: GrzEGORCZYKowA et al. 1998: 225-269.

Levin Beth, Hovav Rappaport Malka. 1995. Unaccusativity. At the Syntax-Lexical Semantics Interface. Cambridge, Mass: MIT Press.

LicA Aneta. 2001. Słownik trudności językowych [A Dictionary of Linguistic Difficulties]. Gdańsk: Wydawnictwo Harmonia.

ŁAZIŃSKi Marek. 2001. "Was für ein Perfekt gibt es im modernen Polnisch?”. Linguistik Online 8(1).

Malchukov Andrej, Siewierska Anna (eds.). 2011. Impersonal Constructions. A Cross-linguistic Perspective. Amsterdam-Philadelphia: John Benjamins.

MarkowsKi Andrzej (ed.). 2004. Wielki stownik poprawnej polszczyzny PWN [Great PWN Dictionary of Correct Polish]. Warszawa: Wydawnictwo Naukowe PWN.

Nedjalkov Vladimir P. (ed.). 1988. Typology of Resultative Constructions. Amsterdam-Philadelphia: John Benjamins.

Nedjalkov Vladimir P. 2001. "Resultative Constructions.” In: Haspelmath et. al. 2001: 928-940.

Nedjalkov Vladimir P., Jaxontov Sergej Je. 1988. “The Typology of Resultative Constructions.” In: Nedjalkov 1988: 3-62.

NKJP = Narodowy Korpus Języka Polskiego. Wersja demonstracyjna [National Corpus of Polish. The Demo Version]. Available online at: http://www.nkjp.pl.

Oesterreicher Henryk. 1926. Imiesłów bierny w języku polskim [Passive Participle in Polish]. Kraków: Nakładem Polskiej Akademii Umiejętności.

SAloni Zygmunt, GruszczyńsKi Włodzimierz, Woliński Marcin, WoŁosz Robert. 2007. Słownik gramatyczny języka polskiego [A Grammatical Dictionary of the Polish Language]. Warszawa: Wiedza Powszechna.

SPEnCER Andrew, Zwicky Arnold M. (eds.). 1988. The Handbook of Morphology . Oxford: Blackwell.

Tedeschi Philip, Zaenen Annie (eds.). 1981. Tense and Aspect. New York: Academic Press.

ToKARski Jan. 2001. Fleksja polska [Polish Inflection]. Warszawa: Wydawnictwo Naukowe PWN.

ZaLeski Jan (ed.). 1972. Symbolae Polonicae in honorem Stanislai Jodłowski. Wrocław: Zakład Narodowy im. Ossolińskich. 